Tropical Journal of Pharmaceutical Research October 2020; 19 (10): 2161-2169

ISSN: $1596-5996$ (print); 1596-9827 (electronic) (C) Pharmacotherapy Group, Faculty of Pharmacy, University of Benin, Benin City, 300001 Nigeria.

\title{
A reliable chromatographic method for the simultaneous determination of ciprofloxacin and moxifloxacin in human serum
}

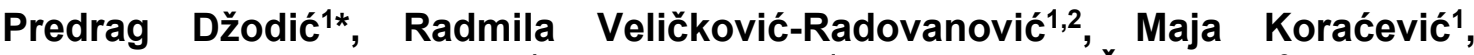 \\ Aleksandra Catić-Đorđević ${ }^{1}$, Ana Spasić ${ }^{1}$, Slavoljub Živanović ${ }^{3}$, Tatjana \\ Cvetković 2,4
}

${ }^{1}$ University of Niš, Faculty of Medicine, Department of Pharmacy, ${ }^{2}$ Clinic of Nephrology, Clinical Centre Niš, ${ }^{3}$ University of Niš, Faculty of Medicine, Research Center for Biomedicine, ${ }^{4}$ University of Nišs, Faculty of Medicine, Department of Biochemistry, Nišs, Serbia

*For correspondence: Email: pdzodic@gmail.com; Tel: 00381184226644

\begin{abstract}
Purpose: To develop and validate a simple chromatographic method for the analysis of ciprofloxacin and moxifloxacin in human serum.

Methods: After protein precipitation had been performed, high performance liquid chromatography (HPLC) with UV detection was utilized for the analysis of ciprofloxacin and moxifloxacin in human serum. Analytical column Zorbax SB-C18 (150 mm x $4.6 \mathrm{~mm}$ i.d., particle size $3.5 \mu \mathrm{m})$ was used as a stationary phase. Chromatographic separation was realized with the mobile phase $0.1 \%$ trifluoroacetic acid in water for chromatography - methanol $(66: 34, \mathrm{v} / \mathrm{v})$, at the flow rate of $1 \mathrm{~mL} / \mathrm{min}$, temperature of 35 ${ }^{\circ} \mathrm{C}$ and detection at $280 \mathrm{~nm}$. The method validation was performed according to the guidelines of the European Medicines Agency (EMA).

Results: The chromatographic run time was about 12 minutes and no interference was observed. For ciprofloxacin, the method was linear over a concentration range of $0.5-50 \mu \mathrm{g} / \mathrm{mL}$, with a correlation coefficient of 0.9874. For moxifloxacin, the method was linear over a concentration range of 0.5-50 $\mu \mathrm{g} / \mathrm{mL}$, with a correlation coefficient of 0.9946 . Since relative standard deviation (RSD) and relative recovery values were within acceptable limits according to EMA guidelines, good intra-day precision, inter-day precision, as well as the accuracy of the method, were observed.

Conclusion: A simple and reliable HPLC-UV method has been developed and validated for the simultaneous determination of ciprofloxacin and moxifloxacin in human serum. The method can be applied for therapeutic drug monitoring but also and pharmacokinetic studies of ciprofloxacin and moxifloxacin.
\end{abstract}

Keywords: Human serum, Ciprofloxacin, Moxifloxacin, Protein precipitation, HPLC, UV detection, Method validation

This is an Open Access article that uses a fund-ing model which does not charge readers or their institutions for access and distributed under the terms of the Creative Commons Attribution License (http://creativecommons.org/licenses/by/4.0) and the Budapest Open Access Initiative (http://www.budapestopenaccessinitiative.org/read), which permit unrestricted use, distribution, and reproduction in any medium, provided the original work is properly credited.

Tropical Journal of Pharmaceutical Research is indexed by Science Citation Index (SciSearch), Scopus, International Pharmaceutical Abstract, Chemical Abstracts, Embase, Index Copernicus, EBSCO, African Index Medicus, JournalSeek, Journal Citation Reports/Science Edition, Directory of Open Access Journals (DOAJ), African Journal Online, Bioline International, Open-J-Gate and Pharmacy Abstracts 


\section{INTRODUCTION}

Ciprofloxacin (CIP) and moxifloxacin (MOX) belong to fluoroquinolones, a class of broadspectrum antibiotics affecting both Gram-positive and Gram-negative bacteria [1]. CIP is a fluoroquinolone with notable antimicrobial activity against Pseudomonas species, Enterobacteriaceae strains resistant to gentamicin, as well as methicillin-resistant Staphylococcus aureus strains. It is usually used for the treatment of urinary, respiratory and gastrointestinal tract infections, some skin, bone, and soft tissue infections [2,3].

Moxifloxacin (MOX), a fourth-generation fluoroquinolone, has a prolonged effect on Grampositive pathogens, including Streptococcus pneumoniae, atypical organisms and anaerobes. This so-called, "respiratory quinolone" is also used in the eradication of Helicobacter pylori. CIP and MOX are both recommended in the treatment of community-acquired pneumonia and as second-line agents for multidrug-resistant tuberculosis [2,4-6].

Owing to worrying antimicrobial resistance, the optimization of traditional antibiotic dosing strategies has received a lot of attention in recent years [7-9]. Fluoroquinolones exhibit concentration-dependent bactericidal activity, so it is important to monitor concentration levels during therapy to accomplish an optimal effect and to avoid resistance [9-11].

Therefore, the target of the present study is the development and validation of a cost-effective method for realizing a simple and reliable highperformance liquid chromatography with UV detection (HPLC-UV) for determining CIP and MOX simultaneously in human serum, which could easily be applied to the therapeutic drug monitoring of CIP and MOX.

Validation was performed according to European Medicines Agency (EMA) guidelines [12] and International Conference on Harmonisation (ICH) guidelines [13]. The proposed method was fully validated in terms of selectivity, linearity, sensitivity, accuracy, precision, absolute recovery and stability of the analytes.

\section{EXPERIMENTAL}

\section{Drugs and materials}

Standard compounds CIP and MOX, in solid form, were kindly donated by the pharmaceutical company Hemofarm (Vršac, Serbia). Internal standard methylparaben (IS), as solid standard compound, was purchased from Sigma-Aldrich (Steinheim, Germany). Methanol gradient grade for liquid chromatography was purchased from Avantor Performance Materials (Deventer, The Netherlands) [14]. Trifluoroacetic acid (TFA) for high-performance liquid chromatography (HPLC) was purchased from Fisher Chemical (Loughborough, UK).

\section{Apparatus}

HPLC analysis was performed using the chromatographic system Agilent Technologies 1200 (Wilmington, DE, USA). A sample of $10 \mu \mathrm{L}$ was injected with Agilent 1200 Series High Performance Autosampler G1367B. HPLC-grade water was acquired from the purification system Smart 2 Pure (TKA, Niederelbert, Germany). The mobile phase was de-gassed and purified by vacuum filtration through $0.45 \mu \mathrm{m}$ regenerated cellulose membrane filters (Agilent, Böblingen, Germany). Zorbax SB-C18 analytical column (150 mm x $4.6 \mathrm{~mm}$ i.d., particle size $3.5 \mu \mathrm{m}$ ) (Agilent, USA) was used for compounds separation [14]. Data were collected using Agilent's ChemStation software. The Microsoft Excel software was used for statistical processing [14].

\section{Chromatographic conditions}

The mobile phase was a mixture of $0.1 \%$ trifluoroacetic acid in water-methanol $(66: 34, \mathrm{v} / \mathrm{v})$. The flow rate was set at $1 \mathrm{~mL} / \mathrm{min}$ and the column temperature at $35^{\circ} \mathrm{C}$. Ultraviolet (UV) detection was performed at $280 \mathrm{~nm}$.

\section{Human serum samples}

Ethical approval for this work was obtained from the Ethics Committee (Ethics Committee of Faculty of Medicine, University of Niš, Serbia; approval number 12-519/3) [14]. The investigations followed the international guidelines, WMA Declaration of Helsinki [15]. Healthy volunteers and patients gave their written informed consent. Blank serum was obtained from ten different healthy volunteers (Clinical Centre Niš, Niš, Serbia). Whole blood was taken by means of venipuncture into vacutainers and, after coagulation, separated by centrifugation at $3000 \mathrm{~g}$ for $15 \mathrm{~min}$ [14]. All serum samples were stored at $-20^{\circ} \mathrm{C}$ until analysis [14].

\section{Standard solutions, calibration standards and quality control samples}

Standard stock solution and standard working solution of CIP contained $5 \mathrm{mg} / \mathrm{mL}$ and $1 \mathrm{mg} / \mathrm{mL}$ in water, respectively. Standard solutions of MOX 
were prepared in the same way. All standard stock and working solutions of CIP and MOX were prepared fresh every day [14].

A standard stock solution of IS was prepared in methanol at a concentration of $5 \mathrm{mg} / \mathrm{mL}$ and kept at $-20^{\circ} \mathrm{C}$. A standard working solution of IS of 1 $\mathrm{mg} / \mathrm{mL}$ in methanol was made and stored at 4$8^{\circ} \mathrm{C}$ for 1 month.

For calibration standards, $300 \mu \mathrm{L}$ of blank human serum was transferred into each of the seven Eppendorf tubes. Afterwards, each of the seven tubes received one of the following volumes $0.15,0.45,1.5,4.5,7.5,13.5$ and $15 \mu \mathrm{L}$ of 1 $\mathrm{mg} / \mathrm{mL}$ CIP and MOX standard working solutions. A volume of $6 \mu \mathrm{L}$ of the $1 \mathrm{mg} / \mathrm{mL}$ IS standard working solution was added to each of the Eppendorf tubes. The concentrations of CIP and MOX in calibration standards were $0.5,1.5$, $5,15,25,45$ and $50 \mu \mathrm{g} / \mathrm{mL}$. Moreover, the concentration of IS in each calibration standard was $20 \mu \mathrm{g} / \mathrm{mL}$.

Zero plasma samples were prepared by adding IS to the blank serum (serum without drugs) in the concentration of $20 \mu \mathrm{g} / \mathrm{mL}$ [14].

Quality control (QC) serum samples were prepared to in the final concentrations of 1.5 $\mu \mathrm{g} / \mathrm{mL}$ (low QC), $25 \mu \mathrm{g} / \mathrm{mL}$ (medium QC) and 45 $\mu \mathrm{g} / \mathrm{mL}$ (high QC) of CIP and MOX. The concentration of is was $20 \mu \mathrm{g} / \mathrm{mL}$. For the optimization of sample preparation procedure, QC (medium) samples were used.

Low $Q C$, medium $Q C$ and high $Q C$ samples were prepared fresh every day. In order to test stability after freeze-thaw cycles as well as long term stability, parts of all low $Q C$ and high $Q C$ samples were kept at $-20^{\circ} \mathrm{C}$ [14].

\section{Sample preparation procedure}

A $300 \mu \mathrm{L}$ aliquot of blank human serum was transferred to a $1.0 \mathrm{~mL}$ Eppendorf tube, followed by $6 \mu \mathrm{L}$ of $1 \mathrm{mg} / \mathrm{mL}$ IS in methanol and $594 \mu \mathrm{L}$ of $0.1 \%$ TFA in methanol $(v / v)$. Each tube was capped, vortexed and mixed for $5 \mathrm{~min}$, and frozen for $15 \mathrm{~min}$ at $-20^{\circ} \mathrm{C}$. After thawing, each tube was centrifuged for $10 \mathrm{~min}$ at $10000 \mathrm{rpm}$ and $4^{\circ} \mathrm{C}$. Finally, at the temperature of $25^{\circ} \mathrm{C}$, the supernatant was injected into the HPLC apparatus for analysis [14].

\section{Validation}

Validation of the proposed method was performed according to European Medicines Agency (EMA) guidelines for Bioanalytical method validation [12], as well as the International Conference on Harmonisation $(\mathrm{ICH})$ guidelines [13]. The following validation characteristics were considered: selectivity, linearity, sensitivity, accuracy, precision, absolute recovery and stability of the analytes [14].

\section{RESULTS}

\section{Selectivity}

To test the selectivity of the method, freshly prepared spiked serum samples of $50 \mu \mathrm{g} / \mathrm{mL}$, as well as $0.5 \mu \mathrm{g} / \mathrm{mL}$ (lower limit of quantification level, LLOQ) of CIP and MOX, were compared to blank serum (without drugs) obtained from ten healthy volunteers. Co-elution was not observed at the retention times of CIP, MOX and IS [14]. Figure 1 shows the representative chromatogram of blank serum.

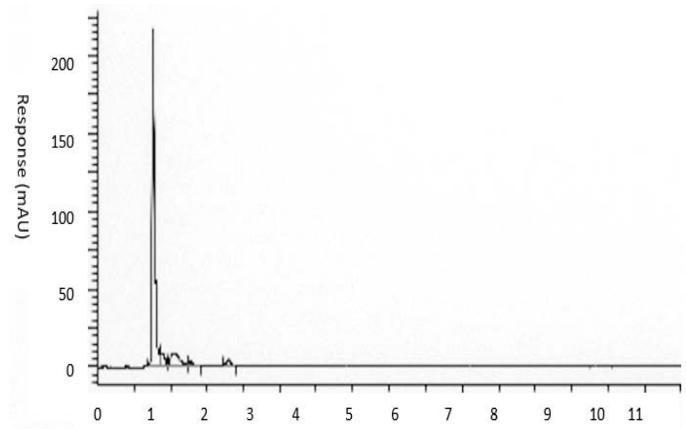

Figure 1: Representative chromatogram of blank serum

In order to thoroughly investigate the selectivity, serum samples were assayed from volunteer patients who were administrated the following drugs: alfacalcidol, amlodipine, atorvastatine, bisoprolol, bromazepam, cefixime, digoxin, felodipine, fluconazole, folic acid, fosinopril, furosemide, irbesartan, isosorbide dinitrate, lercanidipine, metronidazole, nebivolol, pantoprazole, ramipril, rosuvastatin, spironolactone, tamsulosin, telmisartan and warfarin. Co-elution was not observed at the retention times of CIP, MOX and IS [14].

\section{Linearity}

The calibration curves for CIP and MOX were generated after the analysis of seven calibration standards. For the examined concentration range for CIP and MOX (0.5-50 $\mu \mathrm{g} / \mathrm{mL})$, the two calibration curves were obtained based on Eqs 1 and 2.

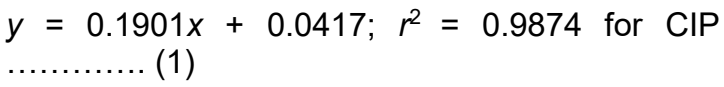

Trop J Pharm Res, October 2020; 19(10): 2163 
$y=0.0930 x+0.0303 ; r^{2}=0.9946$ for $\operatorname{MOX}$ (2)

where $y$ is the peak area ratio, $x$ is the concentration of the compound, and $r$ is the correlation coefficient [16]. The intercepts of the calibration curves were tested using Student's ttest [16]. The following results were calculated for the standard deviation of the slope (Sa), standard deviation of the intercept $(\mathrm{Sb})$ and the confidence factor $\left(t_{\alpha}\right)[16]$ :

$S a=0.0691, S b=1.9199$ and $t_{a}=0.0217$ for CIP; and $S a=0.0041$, $S b=0.1151$ and $t_{\alpha}=$ 0.2635 for MOX. The calculated $t_{\alpha}$ values for CIP and MOX were compared to the tabular $t_{\alpha}$ value ( $p=0.05$ and $t_{t a b}=2.37$ ), and thus the deviation of the intercepts from the zero value was insignificant [14, 16]. Figure 2 shows the representative chromatogram of blank serum spiked with IS. Figure 3 shows the representative chromatogram of blank serum spiked with CIP, MOX and IS.

Limit of detection (LOD) and lower limit of quantification (LLOQ) values for the two analytes were 0.05 and $0.5 \mu \mathrm{g} / \mathrm{mL}$, respectively. The accuracy and precision were evaluated in six replications $(n=6)$ at the LLOQ level. Accuracy is reported as recovery ( $R$ in \%) and precision is reported as relative standard deviation (RSD in $\%)$ [14]. The results obtained for LLOQ are presented in Table 1.

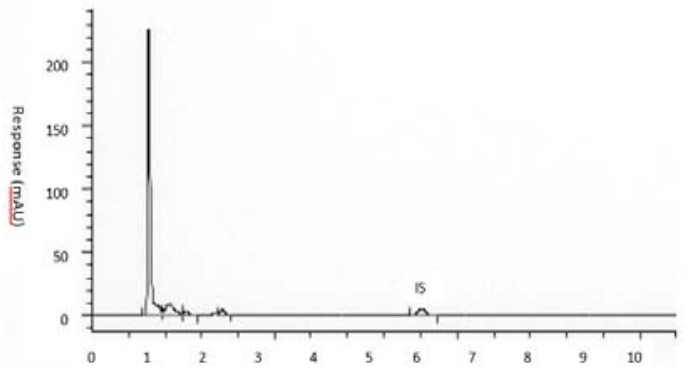

Figure 2: Representative chromatogram of blank serum spiked with $20 \mu \mathrm{g} / \mathrm{mL}$ of IS

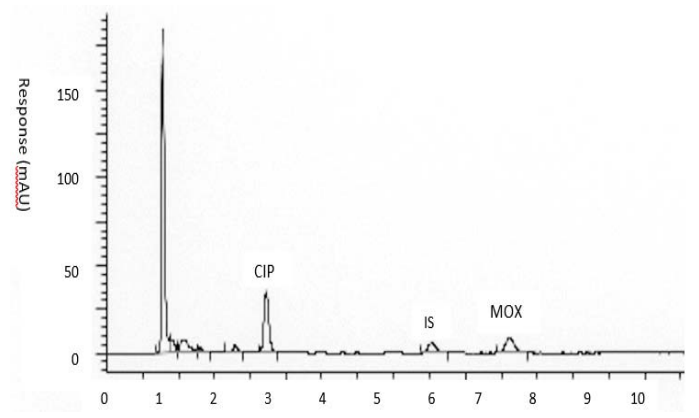

Figure 3: Representative chromatogram of blank serum spiked with $25 \mu \mathrm{g} / \mathrm{mL}$ of CIP and MOX, and 20 $\mu \mathrm{g} / \mathrm{mL}$ of IS

\section{Accuracy and precision}

Intra-day and inter-day accuracy and precision (n = 6) was examined at low QC $(1.5 \mu \mathrm{g} / \mathrm{mL})$, medium QC $(25 \mu \mathrm{g} / \mathrm{mL})$ and high QC $(45 \mu \mathrm{g} / \mathrm{mL})$ levels. Accuracy is reported as recovery ( $R$ in \%) and precision as relative standard deviation (RSD in \%) [14].

Table 1: Intra-day precision and accuracy at LLOQ $(0.5 \mu \mathrm{g} / \mathrm{mL})$, low QC $(1.5 \mu \mathrm{g} / \mathrm{mL})$, medium QC $(25 \mu \mathrm{g} / \mathrm{mL})$, and high QC $(45 \mu \mathrm{g} / \mathrm{mL})$ concentrations in serum samples for CIP and MOX $(\mathrm{n}=6)$

\begin{tabular}{llcccc}
\hline \multirow{2}{*}{ Analyte } & \multirow{2}{*}{ Parameter } & \multicolumn{4}{c}{ Concentration $(\boldsymbol{\mu g} / \mathbf{m L})$ of CIP and MOX } \\
\cline { 3 - 6 } & & $\mathbf{0 . 5}$ & $\mathbf{1 . 5}$ & $\mathbf{2 5}$ & $\mathbf{4 5}$ \\
\hline \multirow{3}{*}{ CIP } & Precision (RSD, \%) & 6.88 & 8.98 & 7.07 & 8.11 \\
& Accuracy (R, \%) & 107.19 & 109.58 & 91.26 & 113.27 \\
& Determined conc. $(\mu \mathrm{g} / \mathrm{mL})$ & 0.54 & 1.64 & 22.81 & 50.97 \\
\multirow{2}{*}{ MOX } & Precision (RSD, \%) & 14.64 & 13.01 & 12.38 & 6.94 \\
& Accuracy (R, \%) & 86.14 & 91.03 & 93.33 & 92.3 \\
& Determined conc. $(\mu \mathrm{g} / \mathrm{mL})$ & 0.43 & 1.37 & 23.33 & 41.53 \\
\hline
\end{tabular}

Table 2: Inter-day precision and accuracy at low QC $(1.5 \mu \mathrm{g} / \mathrm{mL})$, medium $Q C(25 \mu \mathrm{g} / \mathrm{mL})$, and high QC (45 $\mu \mathrm{g} / \mathrm{mL})$ concentrations in serum samples for CIP and MOX $(n=6)$

\begin{tabular}{llccc}
\hline \multirow{2}{*}{ Analyte } & \multirow{2}{*}{ Parameter } & \multicolumn{3}{c}{ Concentration $(\boldsymbol{\mu g} / \mathbf{m L})$ of CIP and MOX } \\
\cline { 3 - 5 } & & $\mathbf{1 . 5}$ & $\mathbf{2 5}$ & $\mathbf{4 5}$ \\
\hline \multirow{3}{*}{ CIP } & Precision (RSD, \%) & 7.62 & 6.01 & 10.07 \\
& Accuracy (R, \%) & 113.75 & 109.91 & 97.22 \\
& Determined conc. $(\mu \mathrm{g} / \mathrm{mL})$ & 1.71 & 27.48 & 43.75 \\
\multirow{2}{*}{ MOX } & Precision (RSD, \%) & 11.55 & 10.68 & 5.23 \\
& Accuracy (R, \%) & 94.14 & 88.92 & 109.29 \\
& Determined conc. $(\mu \mathrm{g} / \mathrm{mL})$ & 1.41 & 22.23 & 49.18 \\
\hline
\end{tabular}


The results obtained for RSD (\%) and recovery $(R, \%)$ are in accordance with the EMA [12] guidelines: at LLOQ level, a precision of $20 \%$ and accuracy of $80-120 \%$; at low QC, medium QC and high QC levels, a precision of $15 \%$ and accuracy of $85-115 \%$. The results obtained are presented in Table 1 and Table 2.

\section{Absolute recovery}

In order to evaluate the efficiency of the sample preparation procedure, absolute recovery values were calculated. Spiked drug-free serum samples at low QC, medium $\mathrm{QC}$ and high $\mathrm{QC}$ were subjected to the sample preparation procedure [14] (as explained in detail in the subsection on the Sample preparation procedure). The above-mentioned samples were compared to blank serum samples, that were extracted following the same sample preparation procedure, and subsequently spiked at the same concentration levels [14]. The absolute recovery values and the estimated concentrations from human serum for CIP and MOX are presented in Table 3.

\section{Stability of the analytes}

According to EMA guidelines [12], the following stability tests were performed at low QC and high QC levels: short-term stability, post-preparative stability, long-term stability and freeze-thaw cycles, and the results are presented in Table 4, Table 5, Table 6 and Table 7, respectively.

Table 3: Absolute recovery values for CIP and MOX from serum samples $(n=6)$

\begin{tabular}{llccc}
\hline \multirow{2}{*}{ Analyte } & \multirow{2}{*}{ Parameter } & \multicolumn{3}{c}{ Concentration $(\boldsymbol{\mu g} / \mathbf{m L})$ of CIP and MOX } \\
\cline { 3 - 5 } & & $\mathbf{1 . 5}$ & $\mathbf{2 5}$ & $\mathbf{4 5}$ \\
\hline \multirow{2}{*}{ CIP } & Recovery $(\%)$ & 93.33 & 107.52 & 104.1 \\
& RSD $(\%)$ & 5.78 & 5.2 & 5.9 \\
& Determined conc. $(\mu \mathrm{g} / \mathrm{mL})$ & 1.4 & 26.88 & 46.84 \\
\multirow{2}{*}{ MOX } & Recovery $(\%)$ & 88,97 & 113.32 & 92.7 \\
& RSD $(\%)$ & 8.22 & 8.87 & 6.38 \\
& Determined conc. $(\mu \mathrm{g} / \mathrm{mL})$ & 1.33 & 28.33 & 41.72 \\
\hline
\end{tabular}

Table 4: Short-term stability results at low $Q C$ and high $Q C$ concentrations in serum samples $(n=6)$

\begin{tabular}{llcc}
\hline \multirow{2}{*}{ Analyte } & \multirow{2}{*}{ Parameter } & \multicolumn{2}{c}{ Concentration $(\boldsymbol{\mu g} / \mathbf{m L})$ of CIP and MOX } \\
\cline { 3 - 4 } & & $\mathbf{1 . 5}$ & $\mathbf{4 5}$ \\
\hline \multirow{2}{*}{ CIP } & Recovery $(\%)$ & 88.54 & 105.14 \\
& RSD $(\%)$ & 11.59 & 7.35 \\
& Determined conc. $(\mu \mathrm{g} / \mathrm{mL})$ & 1.33 & 47.31 \\
\multirow{2}{*}{ MOX } & Recovery $(\%)$ & 108.16 & 95.41 \\
& RSD $(\%)$ & 7.34 & 4.81 \\
& Determined conc. $(\mu \mathrm{g} / \mathrm{mL})$ & 1.62 & 42.93 \\
\hline
\end{tabular}

Table 5: Post-preparative stability results at low $Q C$ and high $Q C$ concentrations in serum samples $(n=6)$

\begin{tabular}{llcc}
\hline \multirow{2}{*}{ Analyte } & \multirow{2}{*}{ Parameter } & \multicolumn{2}{c}{ Concentration $(\boldsymbol{\mu g} / \mathbf{m L})$ of CIP and MOX } \\
\cline { 3 - 4 } & & $\mathbf{1 . 5}$ & $\mathbf{4 5}$ \\
\hline \multirow{2}{*}{ CIP } & Recovery $(\%)$ & 104.86 & 96.25 \\
& RSD $(\%)$ & 9.8 & 10.72 \\
& Determined conc. $(\mu \mathrm{g} / \mathrm{mL})$ & 1.57 & 43.31 \\
\multirow{2}{*}{ MOX } & Recovery $(\%)$ & 111.26 & 92.52 \\
& RSD $(\%)$ & 13.71 & 7.27 \\
& Determined conc. $(\mu \mathrm{g} / \mathrm{mL})$ & 1.7 & 41.63 \\
\hline
\end{tabular}

Table 6: Long-term stability results at low $Q C$ and high $Q C$ concentrations in serum samples $(n=6)$

\begin{tabular}{clcc}
\hline \multirow{2}{*}{ Analyte } & Parameter & \multicolumn{2}{c}{ Concentration $(\boldsymbol{\mu g} / \mathbf{m L})$ of CIP and MOX } \\
\cline { 3 - 4 } & Recovery $(\%)$ & $\mathbf{1 . 5}$ & $\mathbf{4 5}$ \\
\hline \multirow{2}{*}{ CIP } & RSD $(\%)$ & 108.33 & 94.65 \\
& Determined conc. $(\mu \mathrm{g} / \mathrm{mL})$ & 6.93 & 4.93 \\
& Recovery $(\%)$ & 1.62 & 42.59 \\
\multirow{2}{*}{ MOX } & RSD $(\%)$ & 90.8 & 112.59 \\
& Determined conc. $(\mu \mathrm{g} / \mathrm{mL})$ & 9.56 & 9.89 \\
& & 1.36 & 50.66 \\
\hline
\end{tabular}


Table 7: Freeze-thaw stability results at low $Q C$ and high $Q C$ concentrations in serum samples $(n=6)$

\begin{tabular}{llcc}
\hline \multirow{2}{*}{ Analyte } & Parameter & \multicolumn{2}{c}{ Concentration $(\boldsymbol{\mu g} / \mathbf{m L})$ of CIP and MOX } \\
\cline { 3 - 4 } & & $\mathbf{1 . 5}$ & $\mathbf{4 5}$ \\
\hline \multirow{2}{*}{ CIP } & Recovery $(\%)$ & 110.42 & 105.98 \\
& RSD $(\%)$ & 9.43 & 6.06 \\
& Determined conc. $(\mu \mathrm{g} / \mathrm{mL})$ & 1.66 & 47.69 \\
\multirow{2}{*}{ MOX } & Recovery $(\%)$ & 97.13 & 92.09 \\
& RSD $(\%)$ & 11.82 & 7.72 \\
& Determined conc. $(\mu \mathrm{g} / \mathrm{mL})$ & 1.46 & 41.44 \\
\hline
\end{tabular}

\section{DISCUSSION}

According to literature data, the determination of CIP and MOX by HPLC methods has already been performed in human serum [7,17-23,30-34], plasma $[3,4,10,24-29,35-40]$, urine $[17,19,20]$, amniotic fluid [24], peritoneal fluid $[18,19,35]$, peritoneal exudate [41] or ascites [31]. The detectors used in such published papers were: ultraviolet (UV) detection $[3,4,17,21,24,26,29,30$, $35,38,39]$, fluorescence detection [10,17$20,22,23,25-28,31,33,35-37,40,41]$ and MS detection $[7,32,34]$. Sample pretreatment was performed by protein precipitation $[7,17,20$ $22,30,31,34]$, liquid extraction $[18,32]$, continuous dialysis [23], or filtration through the $0.45 \mu \mathrm{m}$ membrane filter, and subsequently dilution [19].

The method described in this paper involves protein precipitation for the purpose of removing proteins and purifying human serum samples. Subsequently, supernatant was injected into the HPLC system; thus, time-consuming evaporation and reconstitution steps were avoided.

Low human serum volume was used for sample preparation, which is convenient for sample handling during method development and validation. In addition, sample pretreatment lasted about $30 \mathrm{~min}$ and chromatographic run time was about $12 \mathrm{~min}$, which is appropriate for the clinical application of the method. Moreover, CIP and MOX in human serum were determined simultaneously.

The proposed HPLC-UV method for the determination of CIP and MOX in human serum has some advantages over the previously published methods. The HPLC-UV apparatus is more affordable than the HPLC-MS one, which is of great importance for the method application in clinical practice. In addition, the method range is wider for the two analytes $(0.5-50 \mu \mathrm{g} / \mathrm{mL})$ in comparison with the published methods $[4,7,12$ $14,17,24,27]$. The proposed method showed good peak symmetry despite the previously observed peak tailing $[21,33,34]$. In addition, the method showed adequate sensitivity and could thus be applied to analysis of human serum samples in pharmacokinetic studies.
The proposed method is selective due to the fact that no co-elution was spotted at the retention times of CIP, MOX and IS from freshly prepared spiked samples at $50 \mu \mathrm{g} / \mathrm{mL}$, as well as 0.5 $\mu \mathrm{g} / \mathrm{mL}$ (LLOQ) for CIP and MOX, compared to blank plasma from ten healthy volunteers [14]. Moreover, an additional selectivity examination of the method was successfully performed with volunteer patients.

For the investigated range for CIP and MOX (0.5$50 \mu \mathrm{g} / \mathrm{mL}), r^{2}$ was equal to 0.9874 and 0.9946 , respectively. Therefore, the linearity of both calibration curves was proven to be good. Furthermore, according to student's t-test, the deviation of the intercepts from the zero value was insignificant $[14,16]$.

The method showed good sensitivity for CIP and MOX since LOD and LLOQ values were 0.05 and $0.5 \mu \mathrm{g} / \mathrm{mL}$, respectively.

Relative standard deviation (RSD in \%) and relative recovery ( $R$ in \%) values were within acceptable limits, according to EMA guidelines [12]. Therefore, a good intra-day precision, interday precision and accuracy of the method were observed.

Regarding the absolute recovery values of CIP and MOX, the sample preparation procedure showed an adequate efficiency. In addition, absolute recovery values appeared to be independent of concentration.

Considering the presented results, CIP and MOX stability was proven in all investigations.

\section{CONCLUSION}

A novel HPLC-UV method has successfully been developed and validated for the analysis of CIP and MOX in human serum. The method is simple, reliable and affordable. Furthermore, the proposed method can be applied to the analysis of CIP and MOX in human serum samples obtained from patients, not only for therapeutic drug monitoring, but also for pharmacokinetic studies.

Trop J Pharm Res, October 2020; 19(10): 2166 


\section{DECLARATIONS}

\section{Acknowledgement}

This research was supported by the Ministry of Education, Science and Technological Development of the Republic of Serbia, as part of project No. 172044 and 41018. The solid standard compounds, CIP and MOX, were kindly provided by the pharmaceutical company, Hemofarm (Vršac, Serbia).

\section{Conflict of interest}

The authors declare that no conflict of interest is associated with this study.

\section{Contribution of authors}

We declare that this work was done by all the authors stated below in this article, and that all liabilities pertaining to claims relating to the content of this article will be borne by the authors. Assistant Professor Predrag Džodić, $\mathrm{PhD}$ conceived and designed the study, collected data and wrote the manuscript.

\section{Open Access}

This is an Open Access article that uses a funding model which does not charge readers or their institutions for access and distributed under the terms of the Creative Commons Attribution License (http://creativecommons.org/licenses/by/ 4.0) and the Budapest Open Access Initiative (http://www.budapestopenaccessinitiative.org/rea d), which permit unrestricted use, distribution, and reproduction in any medium, provided the original work is properly credited.

\section{REFERENCES}

1. Wanger A, Chavez V, Huang RSP, Wahed A, Actor JK, Dasgupta A. Antibiotics, antimicrobial resistance, antibiotic susceptibility testing, and therapeutic drug monitoring for selected drugs. In: Wanger A, Chavez $V$, Huang RSP et al, editors. Microbiology and molecular diagnosis in pathology. Amsterdam: Elsevier 2017; 119153.

2. Hösl J, Gessner A, El-Najjar N. Liquid chromatographytandem mass spectrometry for the quantification of moxifloxacin, ciprofloxacin, daptomycin, caspofungin, and isavuconazole in human plasma. J Pharm Biomed Anal 2018; 157: 92-99.

3. Vella J, Busuttil F, Bartolo NS, Sammut C, Ferrito $V$, Serracino-Inglott A, Azzopardi LM, LaFerla G. A simple HPLC-UV method for the determination of ciprofloxacin in human plasma. J Chromatogr B Analyt Technol Biomed Life Sci 2015; 989: 80-85.

4. Czyrski A, Sokół A, Szałek E. HPLC method for determination of moxifloxacin in plasma and its application in pharmacokinetic analysis. J Liq Chromatogr Relat Technol 2017; 40(1): 8-12.

5. Lode HM. Preserving the efficacy of front-line fluoroquinolones through selective use to optimise clinical outcomes. Int J Antimicrob Agents. 2014; 43(6): 497-507.

6. Zhang GF, Liu X, Zhang S, Pan B, Liu ML. Ciprofloxacin derivatives and their antibacterial activities. Eur $\mathrm{J}$ Med Chem 2018; 146: 599-612.

7. Paal M, Zoller M, Schuster C, Vogeser M, Schütze G. Simultaneous quantification of cefepime, meropenem, ciprofloxacin, moxifloxacin, linezolid and piperacillin in human serum using an isotope-dilution HPLC-MS/MS method. J Pharm Biomed Anal 2018; 152: 102-110.

8. Kuhlin J, Sturkenboom MGG, Ghimire S, Margineanu I, van den Elsen SHJ, Simbar N, Akkerman OW, Jongedijk EM, Koster RA, Bruchfeld J, et al. Mass spectrometry for therapeutic drug monitoring of antituberculosis drugs. Clin Mass Spectrom, 2018 [cited 2019 Jul 05]. Available from: https://doi.org/10.1016/j.clinms.2018.10.002.

9. de Velde F, Mouton JW, de Winter BCM, van Gelder T, Koch BCP. Clinical applications of population pharmacokinetic models of antibiotics: challenges and perspectives. Pharmacol Res 2018; 134: 280-288.

10. Muchohi SN, Thuo N, Karisa J, Muturi A, Kokwaro GO, Maitland K. Determination of ciprofloxacin in human plasma using high-performance liquid chromatography coupled with fluorescence detection: application to a population pharmacokinetics study in children with severe malnutrition. J Chromatogr B Analyt Technol Biomed Life Sci 2011; 879(2): 146-152.

11. Raju KSR, Gundeti M, Malik MY, Kadian N, Rashid M, Taneja I, Singh SP, Wahajuddin M. Bioanalysis of antitubercular drugs using liquid chromatography. J Pharm Biomed Anal 2017; 134: 295-309.

12. European Medicines Agency. Guideline on bioanalytical method validation, 2011 [cited 2019 Jul 05]. Available from:

https://www.ema.europa.eu/en/documents/scientificguideline/guideline-bioanalytical-methodvalidation_en.pdf

13. ICH harmonised tripartite guideline Q2(R1), Validation of analytical procedures: text and methodology. Fed Regist 1997; 62(96): 27463-27467.

14. Džodić $P$, Živanović $L j$, Protić A, Ivanović I, VeličkovićRadovanović $R$, Spasić $M$, Lukić $S$, Živanović $S$. Development and validation of a solid phase extractionHPLC method for the determination of carbamazepine and its metabolites, carbamazepine epoxide and carbamazepine trans-diol, in plasma. J Serb Chem Soc 2012; 77(10): 1423-1436.

15. WMA Declaration of Helsinki - Ethical Principles for Medical Research Involving Human Subjects. World

Trop J Pharm Res, October 2020; 19(10): 2167 
Medical Association. Adopted by the 18th WMA General Assembly, Helsinki, Finland, June 1964. Finally amended by the 64th WMA General Assembly, Fortraleza, Brazil, October 2013. [cited 2020 March 19]. Available from: https://www.wma.net/policies-post/wmadeclaration-of-helsinki-ethical-principles-for-medicalresearch-involving-human-subjects/

16. Ivanović I, Zivanovic $L j$, Zecevic $M$. A stability indicating assay method for cefuroxime axetil and its application to analysis of tablets exposed to accelerated stability test conditions. J Chrom A 2006; 1119: 209-215.

17. Weber A, Chaffin D, Smith A, Opheim KE. Quantitation of ciprofloxacin in body fluids by high-pressure liquid chromatography. Antimicrob Agents Chemother 1985; 27(4): 531-534.

18. Yeung SM, Walker SE, Tailor SA, Awdishu L, Tobe S, Yassa T. Pharmacokinetics of oral ciprofloxacin in continuous cycling peritoneal dialysis. Perit Dial Int 2004; 24(5): 447-453.

19. Shalit I, Greenwood RB, Marks MI, Pederson JA, Frederick DL. Pharmacokinetics of single-dose oral ciprofloxacin in patients undergoing chronic ambulatory peritoneal dialysis. Antimicrob Agents Chemother 1986; 30(1): 152-156.

20. Lubasch A, Keller I, Borner K, Koeppe P, Lode H. Comparative pharmacokinetics of ciprofloxacin, gatifloxacin, grepafloxacin, levofloxacin, trovafloxacin, and moxifloxacin after single oral administration in healthy volunteers. Antimicrob Agents Chemother 2000; 44(10): 2600-2603.

21. Krol GJ, Beck GW, Benham T. HPLC analysis of ciprofloxacin and ciprofloxacin metabolites in body fluids. J Pharm Biomed Anal 1995; 14(1-2): 181-190.

22. Watabe S, Yokoyama $Y$, Nakazawa K, Shinozaki K, Hiraoka R, Takeshita K, Suzuki Y. Simultaneous measurement of pazufloxacin, ciprofloxacin, and levofloxacin in human serum by high-performance liquid chromatography with fluorescence detection. J Chromatogr B Analyt Technol Biomed Life Sci 2010; 878(19): 1555-1561.

23. Zupančić T, Pihlar B. Optimisation of a dialytic set-up for liquid chromatography: automated separation and preconcentration of ciprofloxacin. J Chromatogr A 2002; 975(1): 199-209.

24. Nemutlu E, Kır S, Özyüncü Ö, Beksaç MS. Simultaneous separation and determination of seven quinolones using HPLC: analysis of levofloxacin and moxifloxacin in plasma and amniotic fluid. Chromatographia 2007; 66(1): 15-24.

25. Cavazos-Rocha N, Carmona-Alvarado I, Vera-Cabrera L, Waksman-de-Torres N, de la Luz Salazar-Cavazos M. HPLC method for the simultaneous analysis of fluoroquinolones and oxazolidinones in plasma. $J$ Chromatogr Sci 2014; 52(10): 1281-1287.

26. Liang $H$, Kays MB, Sowinski KM. Separation of levofloxacin, ciprofloxacin, gatifloxacin, moxifloxacin, trovafloxacin and cinoxacin by high-performance liquid chromatography: application to levofloxacin determination in human plasma. $J$ Chromatogr $B$ Analyt Technol Biomed Life Sci 2002; 772(1): 53-63.

27. Vybíralová Z, Nobilis M, Zoulova J, Kvetina J, Petr P. High-performance liquid chromatographic determination of ciprofloxacin in plasma samples. J Pharm Biomed Anal 2005; 37(5): 851-858.

28. Imre S, Dogaru MT, Vari CE, Muntean T, Kelemen L. Validation of an HPLC method for the determination of ciprofloxacin in human plasma. J Pharm Biomed Anal 2003; 33(1): 125-130.

29. El-Kimary El, Khamis EF, Belal SF, Abdel Moneim MM. Sensitive inexpensive chromatographic determination of an antimicrobial combination in human plasma and its pharmacokinetic application. J Chromatogr B Analyt Technol Biomed Life Sci. 2018; 1097-1098: 94-100.

30. Sultana N, Arayne MS, Akhtar M, Shamim S, Gul S, Khan MM. High-performance liquid chromatography assay for moxifloxacin in bulk, pharmaceutical formulations and serum: application to in-vitro metal interactions. J Chin Chem Soc 2010; 57(4A): 708-717.

31. Barth J, Jäger D, Mundkowski R, Drewelow B, Welte $T$, Burkhardt $O$. Single- and multiple-dose pharmacokinetics of intravenous moxifloxacin in patients with severe hepatic impairment. J Antimicrob Chemother 2008; 62(3): 575-578.

32. Han M, Jun SH, Lee JH, Park KU, Song J, Song SH. Method for simultaneous analysis of nine second-line anti-tuberculosis drugs using UPLC-MS/MS. J Antimicrob Chemother 2013; 68(9): 2066-2073.

33. Wiesner G, Martin K, Gertler R, Braun SL, Tassani P, Lange $R$, Gruber $M$. Serum concentrations and pharmacokinetics of moxifloxacin in patients undergoing coronary artery bypass graft surgery with cardiopulmonary bypass. Int J Antimicrob Agents 2013; 41(5): 473-476.

34. Lee SJ, Desta KT, Eum SY, Dartois V, Cho SN, Bae DW, Shin SC. Development and validation of LC-ESI-MS/MS method for analysis of moxifloxacin and levofloxacin in serum of multidrug-resistant tuberculosis patients: potential application as therapeutic drug monitoring tool in medical diagnosis. J Chromatogr B Analyt Technol Biomed Life Sci 2016; 1009-1010: 138-143.

35. Skalioti C, Tsaganos T, Stamatiadis D, GiamarellosBourboulis EJ, Boletis J, Kanellakopoulou K. Pharmacokinetics of moxifloxacin in patients undergoing continuous ambulatory peritoneal dialysis. Perit Dial Int 2009; 29(5): 575-579.

36. Laban-Djurdjević $A$, Jelikić-Stankov $M$, Djurdjević $P$. Optimization and validation of the direct HPLC method for the determination of moxifloxacin in plasma. J Chromatogr B Analyt Technol Biomed Life Sci 2006; 844(1): 104-111.

37. Kees MG, Weber $S$, Kees $F$, Horbach $T$. Pharmacokinetics of moxifloxacin in plasma and tissue of morbidly obese patients. J Antimicrob Chemother 2011; 66(10): 2330-2335.

38. Khan FU, Nasir F, lqbal Z, Khan I, Shahbaz N, Hassan $M$, Ullah F. Simultaneous determination of moxifloxacin

Trop J Pharm Res, October 2020; 19(10): 2168 
and ofloxacin in physiological fluids using high performance liquid chromatography with ultraviolet detection. J Chromatogr B Analyt Technol Biomed Life Sci 2016; 1017-1018: 120-128.

39. $X u Y H$, Li D, Liu XY, Li YZ, Lu J. High performance liquid chromatography assay with ultraviolet detection for moxifloxacin: validation and application to a pharmacokinetic study in Chinese volunteers. J
Chromatogr B Analyt Technol Biomed Life Sci 2010; 878(32): 3437-3441.

40. Tatar Ulu S. High-performance liquid chromatography assay for moxifloxacin: pharmacokinetics in human plasma. J Pharm Biomed Anal 2007; 43(1): 320-324.

41. Stass $H$, Rink $A D$, Delesen $H$, Kubitza D, Vestweber $K H$. Pharmacokinetics and peritoneal penetration of moxifloxacin in peritonitis. I Antimicrob Chemother 2006; 58(3): 693-696. 